Indonesia Journal of Learning Education and Counseling

Website: https://journal.ilininstitute.com/index.php/IJoLEC

Vol 1, No 2, 2019, pp 124-132

p-ISSN:2622-8068 and e-ISSN: $2622-8076$

\title{
The Implementation of Multimedia on Physics Learning Based on Direct Instruction Model in The Topic of Light
}

\author{
Suritno Fayanto ${ }^{1}$, Misrawati ${ }^{2}$, Dwi Sulisworo ${ }^{3}$, Hanin Fathan Nurfina Istiqomah ${ }^{4}$, Luh \\ Sukariasih $^{5}$ \\ ${ }^{1,3}$ Department of Physics Education, Universitas Ahmad Dahlan Yogyakarta, Indonesia \\ Email: suritnofayanto@gmail.com \\ ${ }^{3,5}$ Department of Physics Education, Universitas Halu Oleo, Kendari Sulawesi Tenggara, Indonesia \\ ${ }^{4}$ School of Education, Universiti Teknologi Malaysia, Malaysia
}

\section{Article info}

Artikel history:

Received; January-2018

Revised: January-2019

Accepted: February-2019

Publish: March-2019

DOI: doi.org/10.31960/ ijolec.v1i2.94
Abstract. Student physics learning activities have been successfully analyzed through the direct instruction model using multimedia. This study aims to determine the activities and learning outcomes of students using multimedia. The type of this research is action classroom research and subjects are 33 students of eighth-grade Junior High School 5 Kendari. The results of the analysis show that the direct instruction model using multimedia in physics learning is very suitable for use in the learning process. This can be seen of the learning process among cycle 1 and cycle 2 averaging standards with good categories. It means that the learning outcomes could be improved by using multimedia. This is indicated by the score of students who have increase from cycle I to cycle II. The average score of learning outcomes in the first cycle is 63.73 with a percentage of $54.54 \%$. While the average learning outcomes of the second cycle increased to 73.19 with a percentage of $78.78 \%$.

Coresponden author:

Jalan Pramuka No 42 Umbulharjo Yogyakarta Email: suritnofayanto@gmail.com

Multimedia

Physics learning

Learning activity

Articles with open access under license CC BY-NC-4.0

\section{INTRODUCTION}

One sign to future development for the Indonesian nation is education. Because of it, each person can improve the quality of their existence and be able to participate in development. Physics course is one of the courses that are considered difficult to understand and frightening for most high school students. The fact shows that students difficult to be able to understand Physics must go through sequential stages based on the exercises and learning experiences (Checkley, 2010)

In this case, the uses of media on the learning process have to involved to solve the physics learning problems. To change the assumption that physics is difficult to understand, then the physics teachers must be able to find the difficulties faced by high school students and find solutions to overcome them.

Based on learning process observation at junior high school 2 Kendari. It shows that the learning outcomes students of eighthgrade in physics course, especially in topic of light, are low. This can be seen from the average score of physics learning outcomes in the topic of light $(65.91,66.78$ and 66.88). It means that the score is below the minimum assessment score (Kriteria Ketuntasan Minimum/KKM in Bahasa Indonesia) set by 


\section{5 | Indonesia Journal of Learning Education and Counseling}

the school for the topic of light which is 68 . One of the factors makes it happened. It caused the teacher teaching methods focused on 'chalk and talk' methods that were not supported by interesting media for students (Stosic, 2015). They pay less attention to the learning presented by the teacher.

This data is augmented from the results of interviews. It has been conducted obtained that students difficult to distinguish between reflection and refraction of light on the mirror and lens, and the process of forming the darkness. One of many solutions could improve the teaching and learning. This research tried to make alternative actions that can help teachers. The alternative action is created and use Multimedia as learning media on the topic of light.

Generally, the benefits achieved by using multimedia are more interesting and interactive, the teaching time can be reduced, the quality of student learning be able to improve, and the teaching and learning process can be done anywhere and anytime, and student attitudes can be improved (Ezennia et al., 2016). Jian-hua (2012) in their research said that learning in multimedia forms can increase students' interest and understanding. (Amine et al., 2012)also support the argument, he states that the benefits of multimedia as learning media is the students will be encouraged to pursue knowledge and obtain immediate feedback .

Multimedia in the classroom is developed based on the assumption that the communication process in learning will be more meaningful if using various media for supporting the learning process (Boyer et al., 2009). It can attract students' interest and make it easy to understand the topic. Meanwhile, the Direct Instruction model can be an alternative model to use Multimedia in teaching and learning process (Ruutmann \& Kipper, 2011). In this case, the direct instruction model is a learning model that teacher-centered (Garrett, 2008). It will be able to make students more active, energetic, quality and efficient. Because direct teaching uses planning and implementation carefully. So that each subtopic can be presented in such a way and is expected to be more interesting, effective and essential.

Some researchers have used the direct instruction model, including (Wenno, 2014) who review it in physics learning, but there are some shortcoming i.e. only one laboratory equipment used. Based on these issues, this research was conducted to improve the process and learning outcomes of students based on direct instruction model by using multimedia in physics learning.

\section{METHOD}

This type of research is an action classroom where located at junior high school 5 Kendari. The data are quantitative and qualitative data. Quantitative data were obtained from the learning outcomes test. While the qualitative data was obtained from the observation list. The subjects of research are 33 students (18 male and 15 female) from eighth-grade at junior high school 5 Kendari.

The factor studied were the students' ability, especially about the topic of light in teaching and learning using multimedia, how teacher prepared material about the topic and how the learning model used by using interactive media. This research was conducted in two cycles, each cycle consists of planning, implementation, observation, and reflection. The data analysis used as follows:

a. Determine the student score. It has range 0 to 100 for the essay test Formula (1) used to calculating this part:

$$
X_{i}=\frac{S_{p i}}{S_{m}} \times 100
$$

With,

$X_{i} \quad$ : The final score obtained by the i-student

$S_{p i}:$ The score obtained by i-students

$S_{m}$ : Maximum score achieved by a student (ideal score)

b. Calculate the average score of students by formula (2)

$$
\bar{X}=\frac{\sum_{i=i}^{n} X_{i}}{n}
$$

With,

(Kothari, 2004)

$\bar{X}$ : The average scores

$n$ : The total of students

$X_{i}$ : The score obtained by each student

c. Classify the score

Table 1 below used to characterizing the score of a student 
Table 1. Categorizing the Score of Student

\begin{tabular}{cc}
\hline Score Interval & Explanation \\
\hline $1 \leq X_{i}<2$ & Less \\
$2 \leq X_{i}<3$ & Enough
\end{tabular}

Good

Very good

(Sudjana,

1995)

\section{RESULT AND DISCUSSION}

\section{The results of teacher activities during the learning process}

An overview of teacher activities when managing teaching and learning process base on direct instruction model by using Multimedia on the topic of light shown on Table 2 below:

Table 2. The Results of Teacher Activity in Cycle I and Cycle II

\begin{tabular}{|c|c|c|c|}
\hline \multirow{2}{*}{ No } & \multirow{2}{*}{ Measured aspect } & \multicolumn{2}{|c|}{ Observation Score } \\
\hline & & Cycle 1 & Cycle 2 \\
\hline \multicolumn{4}{|c|}{ A. Opening } \\
\hline \multirow{3}{*}{$\mathrm{I}$} & 1. Deliver the learning objectives. & 4 & 4 \\
\hline & 2. Conduct apperception about the topic. & 3 & 4 \\
\hline & 3. Motivate students to pay attention learning process. & 3 & 4 \\
\hline \multirow{10}{*}{ II } & B. Content & & \\
\hline & 1. Teacher talks about the topic using multimedia & 3 & 4 \\
\hline & $\begin{array}{l}\text { 2. The teacher asks the students to explain the topic } \\
\text { again }\end{array}$ & 3 & 3 \\
\hline & $\begin{array}{l}\text { 3. The teacher provides reinforcement to students who } \\
\text { can answer questions correctly and correct students } \\
\text { who answer incorrectly }\end{array}$ & 3 & 3 \\
\hline & 4. The teacher gives an example problem & 4 & 4 \\
\hline & $\begin{array}{l}\text { 5. The teacher calls one of the students to do it in front of } \\
\text { the class }\end{array}$ & 4 & 4 \\
\hline & 6. The teacher guides the student to work on the problem & 3 & 4 \\
\hline & 7. The teacher gives practice questions that are done & 3 & 4 \\
\hline & individually & 4 & 4 \\
\hline & 8. The teacher collects student answers & & \\
\hline \multirow{3}{*}{ III } & C. Closing & & \\
\hline & $\begin{array}{l}\text { 1. Give individual assignments to students and gather at } \\
\text { the next meeting. }\end{array}$ & 3 & 4 \\
\hline & $\begin{array}{l}\text { 2. Inform the basic competencies and/or indicators to } \\
\text { be achieved as well as and subtopic that should be } \\
\text { learned by students in the next meeting. }\end{array}$ & 3 & 4 \\
\hline
\end{tabular}

\begin{tabular}{|c|c|c|c|}
\hline \multicolumn{4}{|c|}{ D. Class situation } \\
\hline & 1. Students are enthusiastic & 3 & 4 \\
\hline \multirow[t]{5}{*}{ IV } & 2. The teacher is enthusiastic & 4 & 4 \\
\hline & 3. Time according to planning & 3 & 3 \\
\hline & $\begin{array}{l}\text { 4. The teaching and learning process according to the } \\
\text { scenario on the lesson plan }\end{array}$ & 4 & 4 \\
\hline & Average & 3.35 & 3.82 \\
\hline & Category & Very good & Very good \\
\hline
\end{tabular}

Table 2 above shows the average score of teacher activity when managing the teaching and learning process on the first cycle was not maximum. There are some aspects of Direct Instruction (DI) model that the teacher did not pay attention to it. The scores show that more score 3 than 4 . The average in the first cycle is 3.35 which is categorized very well.

Table 2 above shows that the score of teacher activity increases from cycle I to cycle II. The average is 3.35 on cycle I, which 


\section{7 | Indonesia Journal of Learning Education and Counseling}

is categorized very well. That's because of the teacher got many scores 3 when apperception session, motivating students, delivering material, guiding students to answer the questions, giving reinforcement, giving prequestions on slide presentation (multimedia), giving individual assignments and when informing objective of learning for the next meeting. The second cycle shows that there is an increase that compared with the first cycle. It's got 3.82 and very good categories, although there are still some activities that get a score 3. (Tonjo et al., 2017) said that by using direct instruction, it is useful to apply in the learning process, because students work in groups and each is responsible for the success of the group. Also, this method can also reduce noise problems. This will affects student learning achievement after students get the material provided by the teacher. The teacher acts as an information provider, organizer, motivator, director, initiator, transmitter, facilitator, mediator, and evaluator. Learning is not only obtained from the teacher, but knowledge can also be found from the self and the environment so that it can improve student learning achievement (See Figure 4) (Triandini et al., 2017; Arifuddin et al., 2008)

From the results, the teacher has applied the direct instruction model about the topic of light as well, which shows in each phase of learning i.e. delivering the material, asking students to re-explain about the topic, giving example problems, guiding students to solve the problem in front of the class, giving reinforcement the wrong answers and corrected it, giving homework as a follow-up exercise and informing objective of learning next meeting (see Figure 1)

\section{The results of student learning}

Data on the activity of eighth-grade students of Junior High School 2 Kendari during the learning process was taken by observation lists. The observatory given scores on every aspect that have predetermined criteria. It was shown on table 3 that described based on every cycle.

Table 3. The Results of Student Activity on Cycle I

\begin{tabular}{|c|c|c|c|c|}
\hline \multirow{2}{*}{ Measured aspect } & \multicolumn{2}{|c|}{ Score } & \multirow{2}{*}{ Average } & \multirow[b]{2}{*}{ Category } \\
\hline & Meeting 1 & Meeting II & & \\
\hline $\begin{array}{l}\text { 1. Listen or pay attention to the subject } \\
\text { material delivered by the teacher. }\end{array}$ & 3 & 3 & 3 & Good \\
\hline 2. Hear the teacher's question & 3 & 3 & 3 & Good \\
\hline $\begin{array}{l}\text { 3. Raise hand to answer the teacher's } \\
\text { question. }\end{array}$ & 2 & 3 & 2,5 & Enough \\
\hline $\begin{array}{l}\text { 4. Answer the questions given by the } \\
\text { teacher }\end{array}$ & 2 & 2 & 2 & Enough \\
\hline 5. Give the answers to the teacher & 3 & 4 & 3,5 & Good \\
\hline Average & & & 2,8 & Enough \\
\hline
\end{tabular}

*Note: 1 = Poor; 2 = Enough; 3 = Good; 4 = Very good

From Table 3, The average activity of students belongs to the category 'fair'. In the first cycle, the lowest student activity score is 'raise hands to answer the teacher's questions' with a score of 2.5. It means that there are still many students who are shy and afraid to raise their hands. They choose to be quiet even though they know the answer. When students answering the questions given by the teacher, the scores is 2 with 'fair' category. There are some students who have not understood to apply some formulas, but other students have done. For other activities such as listening or paying attention to the subject material given by the teacher, listening to the teacher's questions, and giving the answers to teacher that is 3.5 in the good category (see Table 4). 
Table 4. The Results of Student Activity in Cycle II

\begin{tabular}{|c|c|c|c|c|}
\hline \multirow{2}{*}{ Measured aspect } & \multicolumn{2}{|c|}{ Score } & \multirow{2}{*}{ Average } & \multirow{2}{*}{ Category } \\
\hline & Meeting 1 & Meeting II & & \\
\hline $\begin{array}{l}\text { 1. Listen or give attention to the } \\
\text { subject matter delivered by the } \\
\text { teacher. }\end{array}$ & 3 & 4 & 3.5 & Good \\
\hline 2. Hear the teacher's question & 4 & 4 & 4 & Very good \\
\hline $\begin{array}{l}\text { 3. Raise hand to answer the teacher's } \\
\text { question. }\end{array}$ & 3 & 3 & 3 & Good \\
\hline $\begin{array}{l}\text { 4. Answer the questions given by the } \\
\text { teacher }\end{array}$ & 3 & 3 & 3 & Good \\
\hline 5. Give the answers to the teacher & 4 & 4 & 4 & Very good \\
\hline Average & & & 3.5 & Good \\
\hline
\end{tabular}

*Note : 1 = Poor; 2 = Fair; 3 = Good; 4 = Very good

Table 4 explains that the average score is 3.4 or good category and it is increased from the first cycle. Every aspect observed has increased. The activity got the lowest score in the first cycle that has increased so that the activities in the second cycle obtained an average score of 3.5 or good category. In cycle 1 , student who was bashful and afraid to raise their hands to answer questions had begun to be brave and confident. Some of the students who are not familiar with applying the

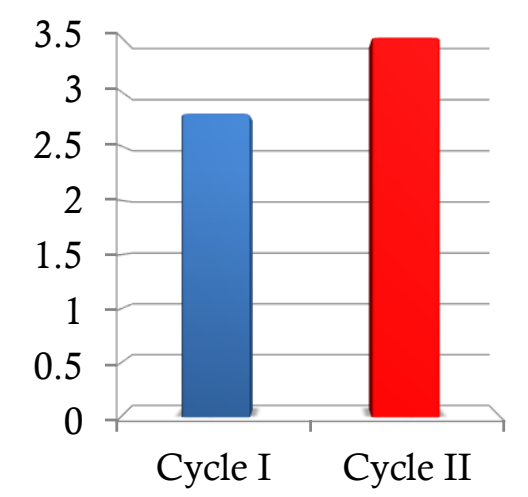

Figure 2. The Enhancement Learning

Table 5 described that the all aspect results of teaching and learning about the topic of light by eighth-grade junior high school 5 Kendari based on direct instruction by using multimedia increased. Figure 3 also explains an increase in students' learning formula had appeared enthusiastic. Enhancement the average shown as figure 2.

This impact the learning outcomes panda in the direct instruction learning model. The teacher prepares to learn begins with small things. The teacher gives detailed and repeated instructions and explanations. The teacher asks many questions and provides opportunities for active practice. They provide feedback and correction in the learning (Jayantilal \& Leary,2016)

Figure 2 shows an increase in the average score from cycle I to cycle I, the score in the first cycle is 2.8 that have increased up to 3.5 in cycle II

\section{The results of student test}

This data were taken by test about the topic of light. Based on the scoring of the test, the result of both cycles shown in Table 5 as follows.

activities from cycle I to cycle II based on the average of scores and minimum score but maximum score decreased. 
129 | Indonesia Journal of Learning Education and Counseling

Table 5. The Results of student test both cycles

\begin{tabular}{|c|c|c|c|c|c|}
\hline \multirow{2}{*}{ No } & \multirow{2}{*}{ Respondent } & \multicolumn{2}{|c|}{ Cycle 1} & \multicolumn{2}{|r|}{ Cycle 2} \\
\hline & & Score & Interpretation & Score & Interpretation \\
\hline 1 & S1 & 80 & $\mathrm{C}$ & 78,4 & $\mathrm{C}$ \\
\hline 2 & S2 & 84,4 & $\mathrm{C}$ & 50,7 & $\mathrm{NC}$ \\
\hline 3 & S3 & 88,8 & $\mathrm{C}$ & 89,2 & $\mathrm{C}$ \\
\hline 4 & S4 & 28,8 & $\mathrm{NC}$ & 66,1 & $\mathrm{NC}$ \\
\hline 5 & S5 & 28,8 & $\mathrm{NC}$ & 50,7 & $\mathrm{NC}$ \\
\hline 6 & S6 & 48,8 & $\mathrm{NC}$ & 69,2 & $\mathrm{C}$ \\
\hline 7 & S7 & 100 & $\mathrm{C}$ & 92,3 & $\mathrm{C}$ \\
\hline 8 & S8 & 28,8 & $\mathrm{NC}$ & 75,3 & $\mathrm{C}$ \\
\hline 9 & S9 & 88,8 & $\mathrm{C}$ & 80 & $\mathrm{C}$ \\
\hline 10 & $\mathrm{~S} 10$ & 42,2 & $\mathrm{NC}$ & 92,3 & $\mathrm{C}$ \\
\hline 11 & $\mathrm{~S} 11$ & 32,2 & $\mathrm{NC}$ & 66,1 & $\mathrm{NC}$ \\
\hline 12 & $\mathrm{~S} 12$ & 84,4 & $\mathrm{C}$ & 69,2 & $\mathrm{C}$ \\
\hline 13 & $\mathrm{~S} 13$ & 75,5 & $\mathrm{C}$ & 72,3 & $\mathrm{C}$ \\
\hline 14 & S14 & 73,3 & $\mathrm{C}$ & 72,3 & $\mathrm{C}$ \\
\hline 15 & $\mathrm{~S} 15$ & 75,5 & $\mathrm{C}$ & 61,5 & $\mathrm{NC}$ \\
\hline 16 & S16 & 60 & $\mathrm{NC}$ & 75,3 & $\mathrm{C}$ \\
\hline 17 & S17 & 28,8 & $\mathrm{NC}$ & 83,0 & $\mathrm{C}$ \\
\hline 18 & S18 & 64,4 & $\mathrm{NC}$ & 86,1 & $\mathrm{C}$ \\
\hline 19 & S19 & 62,2 & $\mathrm{NC}$ & 61,5 & $\mathrm{NC}$ \\
\hline 20 & S20 & 71,1 & $\mathrm{C}$ & 75,3 & $\mathrm{C}$ \\
\hline 21 & $\mathrm{~S} 21$ & 84,4 & $\mathrm{C}$ & 83,1 & $\mathrm{C}$ \\
\hline 22 & S22 & 84,4 & $\mathrm{C}$ & 83,1 & $\mathrm{C}$ \\
\hline 23 & $\mathrm{~S} 23$ & 62,2 & $\mathrm{NC}$ & 86,1 & $\mathrm{C}$ \\
\hline 24 & $\mathrm{~S} 24$ & 84,44 & $\mathrm{C}$ & 69,2 & $\mathrm{C}$ \\
\hline 25 & S25 & 88,8 & $\mathrm{C}$ & 80 & $\mathrm{C}$ \\
\hline 26 & S26 & 73,3 & $\mathrm{C}$ & 69,2 & $\mathrm{C}$ \\
\hline 27 & S27 & 71,1 & $\mathrm{C}$ & 80 & $\mathrm{C}$ \\
\hline 28 & S28 & 64,4 & $\mathrm{NC}$ & 69,2 & $\mathrm{C}$ \\
\hline 29 & S29 & 64,4 & $\mathrm{NC}$ & 69,2 & $\mathrm{C}$ \\
\hline 30 & $\mathrm{~S} 30$ & 77,78 & $\mathrm{C}$ & 69,2 & $\mathrm{C}$ \\
\hline 31 & S31 & 62,22 & $\mathrm{NC}$ & 69,2 & $\mathrm{C}$ \\
\hline 32 & S32 & 73,33 & $\mathrm{C}$ & 69,2 & $\mathrm{C}$ \\
\hline \multirow[t]{9}{*}{33} & S33 & 51,11 & $\mathrm{NC}$ & 50,7 & $\mathrm{NC}$ \\
\hline & & \multicolumn{2}{|r|}{ Cycle I } & \multicolumn{2}{|r|}{ Cycle II } \\
\hline & \multicolumn{2}{|c|}{ Avarage score } & 66,36 & \multicolumn{2}{|r|}{73,19} \\
\hline & \multicolumn{2}{|c|}{ High score } & 100 & \multicolumn{2}{|r|}{92,30} \\
\hline & \multicolumn{2}{|l|}{ Low score } & 28,8 & \multicolumn{2}{|r|}{50,76} \\
\hline & \multicolumn{2}{|c|}{ Complete Total } & 18 & \multicolumn{2}{|r|}{26} \\
\hline & \multicolumn{2}{|c|}{ Not complete total } & 15 & \multicolumn{2}{|r|}{7} \\
\hline & \multicolumn{2}{|c|}{ Complete percentage \%) } & $54,54 \%$ & \multicolumn{2}{|r|}{$78,78 \%$} \\
\hline & \multicolumn{2}{|c|}{ ercentage not complete (\%) } & $45,46 \%$ & \multicolumn{2}{|r|}{$21,22 \%$} \\
\hline
\end{tabular}

*Note $:(\mathrm{C})=$ Complate $;(\mathrm{NC})=$ Not Complete 


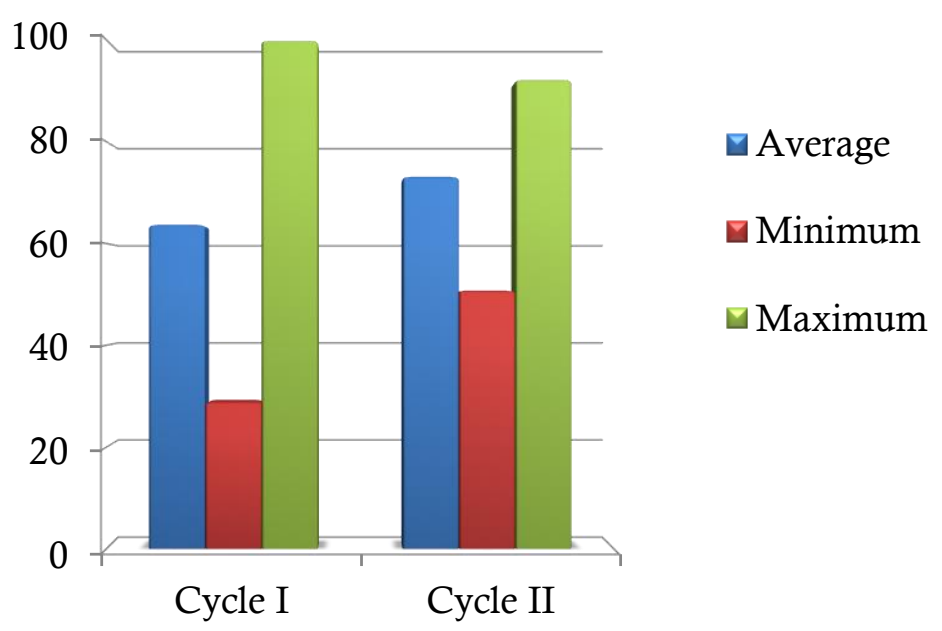

Figure 3. Enhancement of All Aspects

\section{DISCUSSION}

The implementation of classroom action research (Penelitian Tindakan Kelas/PTK in Bahasa Indonesia) based on Direct Instruction model about the topic of light consists of 4 meetings which carried out 2 cycles. Direct instruction models are applied in learning such as the teacher tell about objective learning, the background of the topic, the important learn the topic and the teacher explains all by using multimedia. It helps the teacher for displaying the material of the topic. Furthermore, teacher guide students to solve some problems and answer the questions in whiteboard according to phases of the direct instruction model.

Based on the first objective of research about how the description of student learning activities in the teaching and learning process about the topic of light using multimedia. From observation results both of cycles (cycle I and cycle II) that indicate enhancement significantly. The average results of students learning activity for the cycle I shown in Table 3 and Table 4 for cycle II. The enhancement described that students interest and enthusiasm for following learning activity by using multimedia. These results prove that students are getting used to the learning process applied by the teacher. It makes the students be able to solve the problems that surround them related to the topic. This argument accordance with the (Moeed, 2013), he said that asking students to conduct an investigation means giving them the opportunity to further develop their knowledge. So that they are able to solve problems that will arise in the environment.

The teacher is even more stable in mastering the aspects of managing the direct instruction model. In addition, the teacher also provides reinforcement such as examples of life problem that are often found around. The teacher has started to eliminate the habit of applying conventional learning or monotonous that have been applied too long. This is in accordance with the opinion Felder \& Brent (2018). He said that the difficult topic can learn easily if studied in a pleasant atmosphere, even the topic will be easily understood too.

Furthemore, the answer to the research problem has been revealed, namely, the teaching and learning based on direct instruction model using multimedia have succeeded for enhancement the student ability to achieving the standard of it.

\section{CONCLUSION}

Learning activities of students based on direct instruction model by using multimedia tend to increase and improve every aspect in cycle I and cycle II. This is shown on the average score of the cycle I that has 2.58 or 'fair' category and increases in cycle 2 up to 3.66 or 'good' category. Learning outcomes eighth-grade students of Junior High School 2 Kendari who were taught by using multimedia based on direct instruction model obtained the range of score in the cycle I from 28.8 to 100 . While in the cycle II obtained from 50.76 to 92.30 . It can be improved by using multimedia on teaching and learning 


\section{1 | Indonesia Journal of Learning Education and Counseling}

process. It supported by the score that obtained students. Generally, increase from cycle I to cycle II.

\section{ACKNOWLEDGMENTS}

Thanks to the chairman of physics education department Universitas Halu Oleo, Universitas Ahmad Dahlan and all involved in assisting with funding and facilitating this research.

\section{REFERENCES}

Amine, B. M., Benachaiba, C., \& Guemide, B. (2012). Using multimedia to motivate students in efl classrooms: a case study of english master' $\mathrm{s}$ Students at, 14 (June), 63-81.

Arifuddin, M., Mastuang, Salam, A., \& Mahardika., A. I. (2008). Consistency effectiveness of argumentation strategy in direct instruction model to improve student problem solving skill. Internasional Journal of Advanced Reseacrh, 6 (7), 1222-1225. https:// doi.org/10.21474/IJAR01/7478

Boyer, T. A., Briggeman, B. C., \& Norwood, F. B. (2009). Demand for multimedia in the classroom. Journal of Agricultural and Applied Economics, 3 (December), 791-808.

Checkley, D. (2010). High school students ' perceptions of physics. Lethbridge.

Ezennia, S., Uwajeh, P. C., Agbonome, P. C., \& Iyendo, T. O. (2016). The benefits of digital multimedia as a teaching and learning aid in architectural design studios. International Journal of Current Research, 8(9), 39210-39217.

Felder, R. M., \& Brent, R. (2018). How to improve teaching quality. Quality Management Journal, 6 (2), 1-12.

Garrett, T. (2008). Student-centered and teacher-centered classroom management: a case study of three elementary teachers, 43 (2004), 34-
47.

Jayantilal, K., \& Leary, N. O. (2016). ( Reinforcing ) factors influencing a physical education teacher' $s$ use of the direct instruction model teaching games. European Physical Education Review, 6 (1), 1-20. https://doi. org/10.1177/1356336X16652081

Jian-hua, S. (2012). Explore the effective use of multimedia technology in college physics teaching. International Conference on Future Electrical Power and Energy Systems Explore, 17, 18971900.

https://doi.org/10.1016/j.egypro. 2012.02 .329

Kothari, C. R. (2004). Research methodology (Second Rev). India: New Age International (P) Ltd.

Moeed, A. (2013). Science investigation that best supports student learning: Teachers' understanding of science investigation. International Journal of Environmental \& Science Education, 3(8), 537-559. https://doi.org/ $10.12973 /$ ijese.2013.218a

Ruutmann, T., \& Kipper, R. (2011). Teaching strategies for direct and indirect instruction in teaching engineering. IEEE 14th International Conference on Interactive Collaborative Learning (ICL2011), 107(September), 107-114.

Stosic, L. (2015). The importance of educational technology in teaching . International Journal of Cognitive Research in Science, Engineering and Education, 8(1), 111-114.

Sudjana, N. (1995). Penilaian proses belajar mengajar. Yogyakarta: PT. Rosdakarya.

Tonjo, V. A., Wirjawan, J. V. D., \& Untung, G. B. (2017). Application of direct instruction with laboratory activity to improve students '. International Journal of Social Sciences, 3 (2), 12761284

Triandini, R., \& Siagian, P. (2017). The 
difference of achievement between the students taught by contextual teaching and learning and direct instruction in mathematics grade viii of SMPN 1 tanjung morawa. Paradikma, 10 (1), 88-98.

Wenno, H. (2014). Direct instruction model to increase physical science competence of students as one form of classroom assesment. International Journal of Evaluation and Research in Education (IJERE), 3 (3), 169-174. https://doi.org /10. 11591/ ijere. v3i3. 6492. 